\title{
Evaluation on Business Performance of Chinese Listed Securities Companies-Based on Factor Analysis
}

\author{
Yuan Zhang \\ School of Economics and Management, Beijing Jiaotong University, Beijing, China \\ *Corresponding author.Email:yuanzhangzyx@163.com
}

\begin{abstract}
As an important participant of capital market, security market plays an important role in promoting economic development. With the recovery of stock market, the successive introduction of favorable policies at the regulatory level and the progressive opening to the security market, security industry is faced with great opportunities as well as challenges since 2019. Therefore, this paper made an empirical research on the business performance of Chinese listed securities companies in 2018 by establishing a business performance evaluation system with a sample of 32. Finally, this paper put forward some effective proposals for the future development of securities companies based on the advanced experience of foreign investment banks so that they can better respond to future challenges.
\end{abstract}

Keywords: Chinese listed securities companies, Business performance, Factor analysis.

\section{INTRODUCTION}

The security market plays an important role in the development of a country's economy. It not only provides diversified investment methods for residents, but also serves as an important financing channel for enterprises and it's one of the important ways for government to optimize resource allocation. China's security industry has been developing and growing continuously, but there is still a big gap compared with the banking and insurance industry. Thus it can be seen that under the current economic situation, studying the operating performance of listed companies in China's security industry can not only improve the competitiveness of securities firms, but also promote the development of the whole security industry. Therefore, this paper proposes some constructive opinions and suggestions to improve the development level of the whole securities industry, so as to better serve the development of the real economy.

\section{PRINCIPLE OF FACTOR ANALYSIS AND CONSTRUCTION OF INDEX SYSTEM}

Factor analysis mainly studies the correlation between many variables and finds out a few variables to summarize their internal relations. It is a statistical method to simplify data by reducing dimension.

According to the data released by the Securities Association of China, there were 36 listed securities companies. Four of them were removed from the data collection. The data of 32 listed companies were selected for factor analysis.

In the construction of the performance evaluation index system, factors reflecting the financial innovation ability of enterprises are also taken into account, such as financial products and financial business innovation ability. Some indicators are difficult to quantify, so they are removed. In addition, 18 indicators were selected from six aspects. And they are operation scale, profitability, debt paying ability, development ability, market ability and risk control ability. Specific indicators and calculation methods are as follows: 
Table1. List and stock code of listed securities companies

\begin{tabular}{|c|c|c|c|c|c|}
\hline Number & Securities & Stock Code & Number & Securities & Stock Code \\
\hline 1 & Citic Securities & $600030 . \mathrm{SH}$ & 17 & Dongxing Securities & 601198.SH \\
\hline 2 & Huatai Securities & 601688.SH & 18 & Caitong Securities & 601108.SH \\
\hline 3 & Guotai Junan Securities & 601211.SH & 19 & Zheshang Securities & 601878.SH \\
\hline 4 & Haitong Securities & 600837.SH & 20 & Nanjing Securities & 601990.SH \\
\hline 5 & Guangfa Securities & 000776.SZ & 21 & Guoyuan Securities & 000728.SZ \\
\hline 6 & $\begin{array}{c}\text { Shenwan Hongyuan } \\
\text { Securities }\end{array}$ & 000166.SZ & 22 & Huaxi Securities & 002926.SZ \\
\hline 7 & Merchants Securities & 600999.SH & 23 & Dongwu Securities & 601555.SH \\
\hline 8 & Guosen Securities & 002736.SZ & 24 & Southwest Securities & 600369.SH \\
\hline 9 & China Securities & 601066.SH & 25 & First Capital & 002797.SZ \\
\hline 10 & Orient Securities & 600958.SH & 26 & Sealand Securities & $000750 . \mathrm{SZ}$ \\
\hline 11 & Founder Securities & 601901.SH & 27 & Huaan Securities & 600909.SH \\
\hline 12 & Everbright Securities & 601788.SH & 28 & Shanxi Securities & 002500.SZ \\
\hline 13 & Tianfeng Securities & 601162.SH & 29 & Northeast Securities & 000686.SZ \\
\hline 14 & Industrial Securities & 601377.SH & 30 & Changjiang Securities & 000783.SZ \\
\hline 15 & Great Wall Securities & 002939.SZ & 31 & Guojin Securities & 600109.SH \\
\hline 16 & Western Securities & 002673.SZ & 32 & Hualin Securities & 002945.SZ \\
\hline
\end{tabular}

Table 2. Business performance evaluation system of listed companies

\begin{tabular}{|c|c|c|}
\hline Primary Index & Secondary Index & Name \\
\hline \multirow{4}{*}{ operation scale } & total assets & $\mathrm{X} 1$ \\
\hline & net assets & $\mathrm{X} 2$ \\
\hline & business income & X3 \\
\hline & net profit & $\mathrm{X} 4$ \\
\hline \multirow{4}{*}{ profit ability } & net profit margin & $\mathrm{X} 5$ \\
\hline & ROE & X6 \\
\hline & $\mathrm{ROA}$ & $\mathrm{X7}$ \\
\hline & ROIC & $\mathrm{X} 8$ \\
\hline \multirow{2}{*}{ debt paying ability } & ratio of liabilities & $\mathrm{X} 9$ \\
\hline & equity ratio & $\mathrm{X} 10$ \\
\hline
\end{tabular}




\begin{tabular}{|c|c|c|}
\hline \multirow{3}{*}{ growth ability } & total assets growth rate & $\mathrm{X} 11$ \\
\hline & growth rate of operating profit & $\mathrm{X} 12$ \\
\hline & growth rate of business income & $\mathrm{X} 13$ \\
\hline \multirow{3}{*}{ market ability } & customer fund balance & $\mathrm{X} 14$ \\
\hline & market share of brokerage business & $\mathrm{X} 15$ \\
\hline & market share of underwriting and sponsorship business & $\mathrm{X} 16$ \\
\hline \multirow{2}{*}{ risk control ability } & net capital & $\mathrm{X} 17$ \\
\hline & the ratio of net capital to liabilities & $\mathrm{X} 18$ \\
\hline
\end{tabular}

\section{THE PROCESS AND RESULTS OF FACTOR ANALYSIS}

\subsection{KMO and Bartlett's Test}

Correlation test was conducted, and the KMO value was 0.737 and above 0.7 . The observed value of Bartlett sphericity test statistics is 957.682, which suggests that the correlation coefficient matrix is significantly different from the identity matrix. It can be seen that the data in this paper are suitable for factor analysis.

\subsection{Extract Common Factors}

The principal component method was used to extract common factors, and the number of eigenvalues greater than 1 was selected as the number of common factors. The study shows that the cumulative variance contribution rate of the first 4 factors has reached $90.52 \%$, so the 4 common factors are extracted for analysis.

Table 3. Rotated component matrix

\begin{tabular}{|c|c|c|c|c|}
\hline & \multicolumn{3}{|c|}{ Component } \\
\hline Index & 1 & 2 & 3 & 0.21 \\
\hline X1 & 0.96 & 0.12 & 0.11 & 0.01 \\
\hline X2 & 0.97 & 0.12 & 0.21 & 0.08 \\
\hline X3 & 0.92 & 0.12 & 0.09 & 0.08 \\
\hline X4 & 0.93 & 0.3 & -0.25 & 0.02 \\
\hline X5 & 0.36 & 0.82 & -0.01 & -0.02 \\
\hline X6 & 0.3 & 0.93 & -0.31 & -0.34 \\
\hline X7 & 0.18 & 0.92 & -0.03 & -0.03 \\
\hline X8 & 0.03 & 0.9 & 0.87 & -0.04 \\
\hline X9 & 0.32 & -0.22 & -0.89 & 0.92 \\
\hline X10 & -0.29 & 0.26 & -0.04 & 0.85 \\
\hline X11 & 0.2 & -0.09 & 0.13 & 0.55 \\
\hline
\end{tabular}




\begin{tabular}{|c|c|c|c|c|}
\hline $\mathrm{X} 14$ & 0.95 & 0.2 & 0.14 & 0.03 \\
\hline $\mathrm{X} 15$ & 0.94 & 0.19 & 0.14 & 0.03 \\
\hline $\mathrm{X} 16$ & 0.81 & 0.22 & 0.22 & -0.12 \\
\hline $\mathrm{X} 17$ & 0.13 & 0.12 & 0.96 & 0.02 \\
\hline $\mathrm{X} 18$ & -0.42 & 0.21 & -0.81 & -0.06 \\
\hline
\end{tabular}

\subsection{Rotated Component Matrix}

The common factor is named by analyzing the load of each index on the factor, so that the common factor can explain more information. There are four common factors and they are F1, F2, F3 and F4. F1 factor is named as the market scale factor due to its large load on the four indicators reflecting the operation scale, such as total assets, net assets, business income and net profit, as well as indicators reflecting the market capacity, such as customer fund balance, market share of brokerage business and market share of underwriting and sponsorship business. F2 factor has a large load on four indicators reflecting profitability, such as return on equity, return on assets and return on invested capital. So it is named profitability factor. F3 is named as the solvency risk control factor due to its large load on some indexes reflect the risk control ability and debt paying ability.
F4 has a large load on the growth rate of total assets, growth rate of operating profit and growth rate of operating income, which reflect the development ability. So it is named as the development factor.

\subsection{Calculate the Comprehensive Score and Make Comprehensive Evaluation}

The score function of comprehensive factor is $\mathrm{F}=0.4911 * \mathrm{~F} 1+0.2590 * \mathrm{~F} 2+0.0830 * \mathrm{~F} 3+0.0720 * \mathrm{~F} 4$

According to the score function of comprehensive factor, the comprehensive score of 32 listed security companies can be calculated. According to the factor scores of each company, the ranking of the factor scores of each company can be obtained. The ranking results are shown in the table below:

Table 4. Scores and rank of the listed security companies

\begin{tabular}{|c|c|c|c|c|c|c|}
\hline Securities & $\begin{array}{l}\text { Rank of } \\
\text { F1 }\end{array}$ & $\begin{array}{l}\text { Rank of } \\
\text { F2 }\end{array}$ & $\begin{array}{l}\text { Rank of } \\
\text { F3 }\end{array}$ & $\begin{array}{c}\text { Rank of } \\
\text { F4 }\end{array}$ & $\begin{array}{c}\text { Comprehensive } \\
\text { Score }\end{array}$ & $\begin{array}{c}\text { Rank of Comprehensive } \\
\text { Score }\end{array}$ \\
\hline Citic Securities & 1 & 12 & 19 & 16 & 1.48 & 1 \\
\hline Guotai Junan Securities & 2 & 11 & 26 & 14 & 1.08 & 2 \\
\hline Haitong Securities & 3 & 17 & 10 & 11 & 0.85 & 3 \\
\hline $\begin{array}{c}\text { Shenwan Hongyuan } \\
\text { Securities }\end{array}$ & 7 & 6 & 3 & 2 & 0.78 & 4 \\
\hline Huatai Securities & 4 & 13 & 24 & 29 & 0.72 & 5 \\
\hline Guangfa Securities & 5 & 15 & 15 & 15 & 0.71 & 6 \\
\hline Merchants Securities & 6 & 8 & 21 & 9 & 0.7 & 7 \\
\hline Guosen Securities & 8 & 5 & 7 & 12 & 0.56 & 8 \\
\hline China Securities & 10 & 2 & 4 & 27 & 0.53 & 9 \\
\hline Guojin Securities & 16 & 7 & 31 & 4 & -0.06 & 10 \\
\hline Orient Securities & 11 & 24 & 6 & 24 & -0.08 & 11 \\
\hline
\end{tabular}




\begin{tabular}{|c|c|c|c|c|c|c|}
\hline Dongxing Securities & 27 & 4 & 8 & 20 & -0.1 & 12 \\
\hline Zheshang Securities & 24 & 10 & 11 & 10 & -0.12 & 13 \\
\hline Huaan Securities & 28 & 9 & 20 & 5 & -0.14 & 14 \\
\hline Hualin Securities & 32 & 1 & 13 & 32 & -0.15 & 15 \\
\hline Huaxi Securities & 26 & 3 & 30 & 22 & -0.18 & 16 \\
\hline Founder Securities & 14 & 25 & 12 & 17 & -0.19 & 17 \\
\hline Everbright Securities & 9 & 32 & 17 & 23 & -0.21 & 18 \\
\hline Great Wall Securities & 21 & 14 & 27 & 6 & -0.24 & 19 \\
\hline Caitong Securities & 18 & 16 & 28 & 18 & -0.29 & 20 \\
\hline Industrial Securities & 12 & 31 & 14 & 26 & -0.34 & 21 \\
\hline Guoyuan Securities & 17 & 19 & 25 & 25 & -0.34 & 22 \\
\hline Shanxi Securities & 31 & 18 & 1 & 1 & -0.34 & 23 \\
\hline Northeast Securities & 30 & 22 & 2 & 3 & -0.37 & 24 \\
\hline Tianfeng Securities & 29 & 20 & 16 & 8 & -0.4 & 25 \\
\hline Dongwu Securities & 23 & 23 & 5 & 30 & -0.44 & 26 \\
\hline Nanjing Securities & 20 & 21 & 32 & 7 & -0.51 & 27 \\
\hline Southwest Securities & 19 & 27 & 23 & 13 & -0.53 & 28 \\
\hline Changjiang Securities & 13 & 30 & 22 & 31 & -0.53 & 29 \\
\hline Western Securities & 15 & 29 & 29 & 21 & -0.61 & 30 \\
\hline First Capital & 25 & 26 & 18 & 19 & -0.62 & 31 \\
\hline Sealand Securities & 22 & 28 & 9 & 28 & -0.62 & 32 \\
\hline
\end{tabular}

According to the law of increasing returns to scale, the operating profit of enterprises increases with the expansion of production scale within a certain limit. This law also exists in the securities industry, and the operating performance of large-scaled companies is often better than that of small-scaled companies. In addition, among the 32 listed companies in the securities industry, $50 \%$ of the enterprises' profitability factor score is negative, indicating that the profitability of listed companies in the security industry in China needs to be improved urgently. The comprehensive score and the rank of it shows that the overall development level of listed companies in the securities industry is not high and the development is not balanced. Among the 32 listed companies in the securities industry, there were 9 enterprises with positive comprehensive scores and 23 enterprises with negative comprehensive scores, accounting for $72 \%$ of the sample. Among them, Citic Securities got the highest comprehensive score of 1.48 , while Western Securities, First Venture and Sealand Securities got the lowest comprehensive score of -0.62 . There is a large gap between them.

\section{POLICY RECOMMENDATIONS}

First, large securities firms need to make full use of policy. Small and medium-sized securities firms are supposed to pay more attention to develop their business characteristics. The total assets of American investment bank Goldman Sachs is 6 trillion yuan and it's about 12 times of China's largest securities firm Citic Securities by the end of 2018. Large securities firms still have room for improvement. So they should expand business scale and enhance their own strength among security 
companies. In addition, with the gradual acceleration of business integration in the securities industry, small and medium-sized securities firms should pay attention to the cultivation of characteristic business if they want to get rid of the fate of being merged and integrated. They need to focus on their comparative advantages and provide differentiated and personalized services for different customers, so as to form a unique profit model different from large securities firms.

Secondly, continue to promote financial technology innovation and build differentiated competitive advantages. Financial innovation is an important engine to promote the development of economy. Financial technology combines the traditional financial industry with the modern information technology to promote the development of companies. Therefore, continue to promote the financial technology innovation is particularly important. Securities companies, especially the listed securities firms shall pay more attention to the application of financial technology, such as artificial intelligence, big data, cloud computing, block chain and so on. According to China securities industry association, Guotai Junan is the top investor in information technology in 2018. Compared with the international investment Bank Morgan Stanley, there is still a big gap between them. So domestic securities companies should strengthen the use of information technology and create differentiated competitive advantage.

Thirdly, expand revenue sources and focus on high value-added business development. The income of China's securities firms is mainly composed of traditional business which is very vulnerable to market risk. While the income of large foreign investment banks and a financial institution mainly comes from the high value-added business such as consulting business and financial advisory business. Therefore, Chinese securities firms should strive for business innovation and pay attention to the development of high value-added business, so as to realize the transformation from "trading center" to "asset management center" as soon as possible.

\section{CONCLUSION}

The overall development level of Chinese listed securities companies is not high and uneven, so the profitability needs to be improved.Secondly, the overall debt scale of securities industry is on the rise, which puts forward high requirements for its liquidity management ability and risk control ability.Finally, due to the scale advantage, large securities firms tend to perform well, while small securities firms do not have the scale advantage, but their operation is more flexible. If they find a suitable development path, they can make a lot of improvement.

\section{REFERENCES}

[1] Debdas Rakshit. EVA based performance measurement: a case study of Dabur India limited [J]. Vidyasagar University Journal of Commerce, 2006, 12(11):40-59

[2] Torkamani et al. Performance Evaluation Using the Balanced Score Card (BSC): A Case Study of Azerbaijan Regional Electric Company[J], Journal of Basic and Applied Scientific Research,2(4), 2012:3289-3293.

[3] Drunker P. Harvard business review on measuring corporate performance [J]. Harvard Business review, 1998. (2):16-20.

[4] A.H.Vause.Guide to Analyzing Companies [M].London: CITIC Publishing House, 2003:22-25

[5] Liu Ye. Evaluation on Competence of Chinese Securities Companies Based on Twenty-five Listed Securities Companies' Data[D]. Guangdong University of Foreign Studies, 2018

[6] Xu Chen, Research on the Business Performance of H Securities Company and Its Influencing Factors [D]. Nanjing University of Aeronautics and Astronautics, 2018 